\title{
Zeszyty PRASOZNAWGE
}

Kraków 2020, t. 63, nr 1 (241), s. 55-68

DOI: 10.4467/22996362PZ.20.004.11512

www.ejournals.eu/Zeszyty-Prasoznawcze/

\section{SPOSOBY BADANIA WARTOŚCI EKONOMICZNEJ MEDIÓW}

\author{
Jolanta Dzierżyńska-Mielczarek \\ (iD) orcid.org/0000-0003-0250-6753 \\ Instytut Dziennikarstwa i Informacji \\ Uniwersytet Jana Kochanowskiego w Kielcach
}

\begin{abstract}
Research in the Economic Value of the Media

Economic analyzes of the media's share in the economy are based on measuring advertising and consumer spending on the media. They do not take into account changes in the costs of production and distribution of utilities due to their digitization. New technologies have led to non-institutional media production and the distribution, privatization of profits and socialization of media production costs. This requires the development of new indicators to measure the impact of the media industry on the economy. The article, based on publicly available data, presents various methods of research in the economic value of the traditional media and points out that their seemingly decreasing share in the economy is caused by the fact that the consumer spending on online media content and the revenue of media companies from online advertising is not taken into account in public statistics. It also signals that the digitization of media (including the virtualization of production and consumption of media content) has changed the definition and the boundaries of the media industry.
\end{abstract}

Keywords: media economics, media shares in economy, consumer spending, advertising revenue, research methods

\section{Problem badawczy}

Chociaż media są ważnym elementem współczesnego życia społecznego i przypisuje się im znaczny udział w gospodarce, rzadko podejmuje się wysiłek zmierzenia ich wartości ekonomicznej. Takie pojęcia jak gospodarka oparta na wiedzy czy społeczeństwo informacyjne wciąż pozostają konstruktem teoretycznym, między innymi z powodu problemów $\mathrm{z}$ ich definiowaniem i pomiarem. 
Mediocentrycznym teoriom o rosnącej roli informacji w rozwoju społecznym i wzroście gospodarczym towarzyszy przekonanie o głębokim kryzysie tradycyjnych środków masowej informacji w epoce cyfrowej. Ustępują one miejsca pozainstytucjonalnej produkcji i dystrybucji mediów (twórczości amatorskiej, wspólnotowym formom rozpowszechniania treści medialnych). Zmienia się podmiotowe i przedmiotowe rozumienie przemysłu medialnego. Nie znajduje to odzwierciedlenia w analizach ekonomicznych, które bazując na pomiarach wydatków reklamowych i konsumenckich na media, nie uwzględniają zjawiska prywatyzowania zysków oraz uspołeczniania kosztów produkcji mediów.

Niniejszy artykuł prezentuje sposoby badania wartości ekonomicznej mediów. Zwraca też uwagę na potrzebę stworzenia nowych narzędzi analizowania udziału mediów w gospodarce ze względu na zmianę kosztów ich produkcji i dystrybucji.

\section{Stan badań}

Od pewnego czasu prowadzi się analizy społeczno-ekonomicznego oddziaływania mediów jako sektora kultury i przemysłów kreatywnych. Ma to związek z przekonaniem, że kultura i twórczość mogą stać się motorem wzrostu gospodarczego w Europie i wzmocnić jej pozycję w zglobalizowanej gospodarce. Przełomowy dla takiego postrzegania kultury był raport „The Economy of Culture in Europe” belgijskiego instytutu badawczo-rozwojowego KEA European Affairs, przygotowany na zlecenie Komisji Europejskiej w 2006 roku (KEA 2006), oraz dokument „Green Paper - Unlocking the potential of cultural and creative industries” (KE 2010a). Komisja Europejska przygotowała na tej podstawie wiele programów wsparcia dla sektorów kultury i kreatywnych¹.

Za miernik znaczenia ekonomicznego kultury (w tym mediów) uznaje się wartość dodaną i zatrudnienie w tych sektorach gospodarki. Trudności w definiowaniu branży oraz niedostosowanie statystyk publicznych do prowadzenia badań powodują jednak różnice w ocenie potencjału przemysłów kultury i kreatywnych².

1 Zob. m.in. Europa 2020. Strategia na rzecz inteligentnego i zrównoważonego rozwoju sprzyjającego włączeniu społecznemu (KE 2010b); Program „Kreatywna Europa” (PE 2013).

2 Wkład sektora kultury i sektora kreatywnego do PKB Unii Europejskiej w 2008 roku szacowano na 4,5\%, a zatrudnienie w nim na 8,5 mln osób (TERA Consultants 2010, s. 4). Według European Competitiveness Report sektor kreatywny stanowił 3,3\% PKB w 2006 roku i zatrudniał 6,7 mln osób w 2008 roku (European Competitiveness Report 2010, s. 167). Przygotowany przez Ernst \& Young raport na temat wpływu przemysłów kreatywnych na wzrost gospodarczy UE wskazywał, że przemysły kultury i przemysły kreatywne odpowiadały w 2012 roku za 4,2\% PKB UE i zapewniały blisko $7 \mathrm{mln}$ miejsc pracy (czyli 2,5 razy więcej niż przemysł motoryzacyjny i pięciokrotnie więcej niż przemysł chemiczny) (Ernst \& Young 2014). W projekcie rezolucji Parlamentu Europejskiego w sprawie spójnej polityki UE dla sektora kultury i sektora kreatywnego z listopada 2016 roku udział branż kulturalnej i kreatywnej w PKB oceniono na 5,3\%, a zatrudnienie na $12 \mathrm{mln}$ pełnoetatowych miejsc pracy (co stanowiło 7,5\% czynnej zawodowo populacji UE) (PE 2016). 
W Polsce analizy ekonomicznego znaczenia kultury prowadzone są od niedawna. Sektor medialny nie jest w nich wyraźnie zdefiniowany i wyodrębniony, chociaż działalność wydawnicza, produkcja audiowizualna, nadawanie programów oraz działalność agencji reklamowych osiągają wysoki udział w wartości dodanej i zatrudnieniu w sektorze kultury (Ecorys 2006, IBS 2010, IBS 2017).

W amerykańskich badaniach miernikiem znaczenia ekonomicznego sektora medialnego są konsumpcyjne i reklamowe wydatki na media. Wiele uwagi poświęca się analizom relacji między gospodarką a reklamą (zob. na przykład Demers 1994, Dimmick 1997, Picard 2001, van der Wurff et al. 2008). Potwierdzają one korelację między wysokością wydatków reklamowych a wielkością gospodarki mierzoną za pomocą takich wskaźników jak np. produkt krajowy brutto lub dochód rozporządzalny. Hipoteza stałości wydatków konsumpcyjnych i reklamowych na media w dochodzie narodowym sformułowana przez McCombsa (McCombs 1972) uzupełniana jest obecnie o badania wpływu, jaki na wielkość i dynamikę wydatków na media wywierają takie czynniki, jak poziom rozwoju społeczno-ekonomicznego analizowanego kraju, pojawienie się nowych technologii, zmiany własnościowe na rynku mediów, przeobrażenia polityczne czy kulturowe (Woźniczka 2014).

Nie prowadzi się analiz uwzględniających zmianę kosztów produkcji i dystrybucji mediów, zjawisko społecznej produkcji mediów i powstanie nowych platform dystrybucji treści medialnych.

\section{Media jako element przemystów kreatywnych}

Wszystkie badania nad udziałem kultury i sektorów kreatywnych w gospodarce przypisują mediom dominującą rolę w strukturze wartości dodanej tych sektorów. Według raportu „Kultura jako źródło wzrostu gospodarczego w Unii Europejskiej” branże medialne (gazety i czasopisma, telewizja, radio, branża muzyczna i reklamowa) w 2012 roku odpowiadały za 42\% sprzedaży na rynku kultury i na rynku kreatywnym, co przekładało się na prawie 2\% PKB UE (Ernst \& Young 2014).

Sektor mediów w Polsce w 2015 roku wytwarzał aż 60\% wartości dodanej sektora kultury, czyli prawie 20 mld zł. Największy wkład wnosiła telewizja - 5,6 mld, agencje reklamowe - 4,9 mld, wydawanie książek, gazet i czasopism - 3,5 mld, produkcja i dystrybucja filmów oraz programów telewizyjnych - 1,6 mld. Łączną wartość dodaną sprzedaży gazet, książek, muzyki i nagrań wideo, działalności radiowej oraz kina można szacować na kolejne 1,6 mld zł. W sektorze mediów pracowało w tym czasie około 111 tys. osób, co stanowiło niespełna 40\% zatrudnionych w sektorze kultury. Najwięcej pracowników było w agencjach reklamowych - 30 tys. osób, w wydawnictwach - 27 tys. osób, w telewizji - 18 tys. osób oraz przy produkcji i dystrybucji filmów i programów telewizyjnych - 18 tys. osób. Przy sprzedaży gazet, książek muzyki i nagrań wideo pracowało około 9 tys. osób, podobnie jak w radiu oraz kinach (IBS 2017, s. 19-20).

Autorzy raportu „Znaczenie gospodarcze sektora kultury w Polsce w latach 2008-2015” szacowali, że udział wartości dodanej wytwarzanej przez sektor kultury 
w 2015 roku w produkcie krajowym brutto wyniósł 1,7\%, a zatrudnienie 1,9\% (IBS 2017, s. 18). Dla sektora mediów wartości te należy pomniejszyć o około $40 \%$ i $60 \%$.

Pozycja mediów w gospodarce i perspektywy ich rozwoju są determinowane przez czynniki makroekonomiczne. Szczególnie istotne są te wpływające na kondycję różnych sektorów gospodarki i wysokość ich budżetów marketingowych oraz warunkujące popyt na media ze strony gospodarstw domowych. Zalicza się do nich dynamikę wzrostu gospodarczego, poziom bezrobocia, stopę inflacji, politykę fiskalną, monetarną itp. (por. m.in. Kowalski, Jung 2006, s. 17-18). Sytuacja rynkowa mediów związana jest też z tendencjami demograficznymi w społeczeństwie, z polityką państwa wobec mediów, z rozwojem technologii medialnych, ze zmianami stylu życia.

\section{Wydatki reklamowe na media}

Znaczenie dynamiki wzrostu PKB dla funkcjonowania mediów wiąże się z przekonaniem, że poziom wydatków reklamowych w mediach zależy od kondycji całej gospodarki. Korelacja między dynamiką gospodarki (koniunktura, stagnacja, recesja) a poziomem wydatków reklamowych jest silniejsza w okresach wzrostu gospodarczego, kiedy większość przedsiębiorstw zwiększa swoje budżety reklamowe, i słabsza w okresach recesji, kiedy to część przedsiębiorstw, wbrew gorszej koniunkturze, nie zmniejsza wydatków na reklamę (zob. Picard 2001; Andras, Srinivasan 2003).

Zasada stałych wydatków, czyli wiązania wysokości wydatków reklamowych z poziomem gospodarki, nie okazała się wystarczającą podstawą do wyjaśnienia mechanizmów rządzących wielkością i dynamiką wydatków na media. Wielu badaczy jest zdania, że wydatki na media w większym stopniu zależą od poziomu złożoności życia społecznego niż zmian zachodzących w gospodarce (Demers 1994, s. 32). Zgodnie z hipotezą pluralizmu strukturalnego są one wyższe w pluralistycznych systemach. Pluralizm strukturalny to rosnąca liczba i zróżnicowanie podmiotów gospodarczych i społecznych w danym kraju. Wymóg zbiorowego działania, kooperacji i współpracy w rozwiązywaniu problemów zwiększa znaczenie komunikacji w skali masowej. Oznacza to wzrost liczby i różnorodności mediów, a tym samym zwiększenie wydatków reklamowych w mediach (Dziomdziora 2015, s. 33).

Pluralizmem strukturalnym można wyjaśnić m.in. fakt, że udział wydatków reklamowych na media w PKB jest większy w krajach wysokorozwiniętych, o wyższym poziomie industrializacji i urbanizacji, bardziej konkurencyjnych gospodarkach, z dużym udziałem produkcji dóbr wysoko przetworzonych (Demers 1994; Dimmick 1997; van der Wurff et al. 2008).

Charakteryzując rynek reklamy w Polsce, można stwierdzić, że do 2000 roku wzrastał on $\mathrm{w}$ tempie kilkunastu do kilkudziesięciu procent rocznie, osiągając poziom 0,65\% PKB (Jakubowicz, Jung, Kowalski 2004). Spowolnienie wzrostu gospodarczego, a zwłaszcza kryzysy w latach 2001-2003 oraz po 2008 roku, wyraźnie odbiły się na wydatkach reklamowych. Udział wydatków reklamowych w PKB 
malał. Zmiana metodologii liczenia rynku reklamy online w 2015 roku tylko czasowo odwróciła ten trend (wykres 1).

Wykres 1. Udział reklamy w PKB (w \%)

0,6

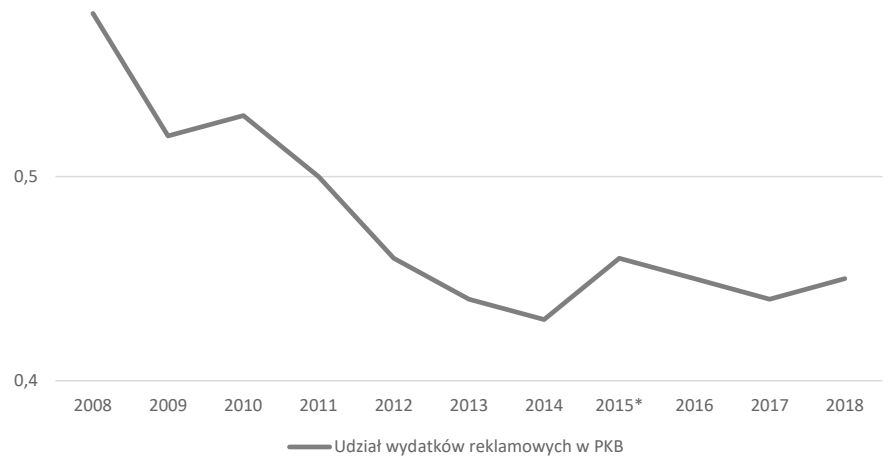

* Zmiana metodologii liczenia rynku reklamy online

Źródło: dane Domu Mediowego Starlink/Starcom (Starlink/

Starcom 2008-2018) oraz GUS (GUS 2008-2018).

Dużym spadkom wydatków reklamowych w okresie spowolnienia gospodarczego nie towarzyszył silniejszy wzrost w czasie poprawy koniunktury. W 2015 roku dynamika wzrostu nakładów na reklamę przewyższyła znacznie dynamikę wzrostu PKB dzięki zmianie sposobu liczenia reklamy internetowej. Wstępne szacunki wskazują, że wyższą dynamikę wzrostu wydatki reklamowe osiągnęły również w 2018 roku (wykres 2).

Wykres 2. Dynamika wydatków reklamowych w stosunku do dynamiki PKB (w \%)

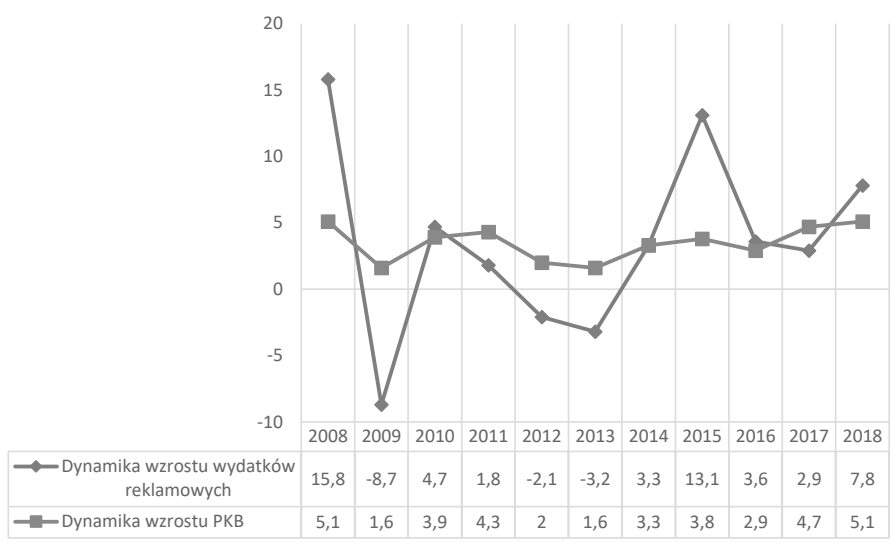

Źródło: dane Domu Mediowego Starlink/Starcom (Starlink/ starcom 2008-2018) oraz GUS (GUS 2008-2018). 
W Polsce na relacje między gospodarką a reklamą medialną mają wpływ czynniki geopolityczne. Dobre prognozy gospodarcze dla Polski (wzrost PKB, dobre nastroje konsumenckie, spadek bezrobocia) nie zawsze przekładały się na widoczny wzrost rynku reklamowego m.in. z powodu sytuacji politycznej i gospodarczej w regionie (konflikt na Ukrainie, recesja w Rosji i na Białorusi), w Europie (skutki decyzji o brexicie, sytuacja wewnątrz Unii Europejskiej, zagrożenie terroryzmem i kryzysem imigracyjnym) oraz na świecie (perspektywy gospodarki amerykańskiej czy chińskiej). Wpływ koniunktury na świecie odbijał się na wydatkach reklamowych w Polsce chociażby z tego względu, że największymi reklamodawcami są tu firmy międzynarodowe.

Ograniczony związek między koniunkturą gospodarczą a wydatkami na media występował też w okresach pojawiania się nowych technologii medialnych i możliwości reklamowych. Rozwój telewizji satelitarnej i kablowej na początku XXI wieku zaowocował wzrostem rynku reklamy mimo braku ożywienia gospodarczego, a wydatki reklamowe na media cyfrowe rosły nawet w okresie światowego kryzysu gospodarczego po 2008 roku. Jednocześnie różne media wykazywały odmienną podatność na zmiany w poziomie wzrostu gospodarczego. Szczególną wrażliwość na dekoniunkturę gospodarczą wykazywała na przykład reklama prasowa.

Na polskim rynku reklamowym widać wyraźny wpływ zmian technologicznych w mediach i powodowanych nimi przeobrażeń w konsumpcji mediów na sposób relokacji wydatków reklamowych. Wzrostowi udziału internetu w wydatkach reklamowych towarzyszyły spadki wydatków reklamowych w telewizji oraz w prasie (w dziennikach i czasopismach) oraz stabilizacja wydatków reklamowych w radiu i w kinie (wykres 3).

Wykres 3. Udział poszczególnych mediów w wydatkach na reklamę ogółem w Polsce w latach 2001-2018 (w \%)

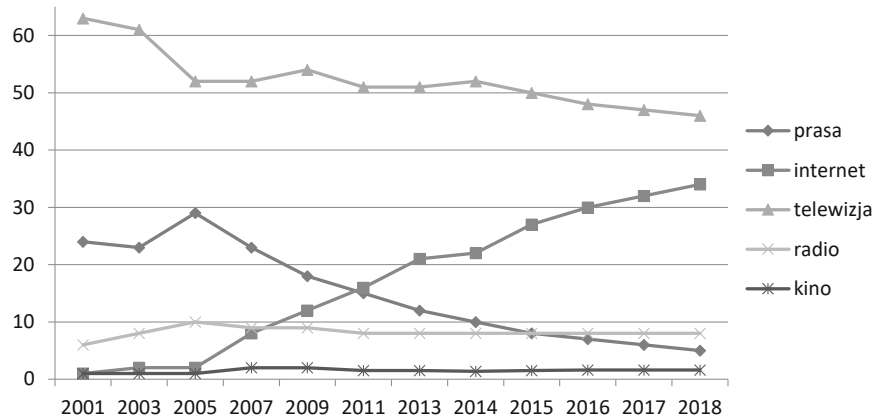

Źródło: Statistical Fact Book 2010 oraz dane Starlink/Starcom (Starlink/Starcom 2008-2018).

Prognozowanie sytuacji na rynku reklamy jest trudnym zadaniem. Poza czynnikami o charakterze makroekonomicznym oraz koniunkturą w branżach, które inwestują w reklamę medialną największe sumy (handel, farmacja, żywność, telekomunikacja, finanse, motoryzacja), wpływ na rynek reklamy mają zmiany technologiczne w samych mediach oraz sposobach ich konsumpcji. Za czynnik 
sprzyjający wzrostowi rynku reklamy uznawano rozwój kolejnych platform dostarczania treści medialnych odbiorcom (nowe kanały telewizyjne, rozwój contentu audiowizualnego $\mathrm{w}$ internecie, serwisy społecznościowe, nowe rozwiązania mobilne itp.). Większa liczba kanałów dystrybucji treści sprzyjała aktywności marketingowej małych i średnich firm, które zyskiwały w ten sposób możliwość promocji swoich produktów i usług. Zwiększeniu wydatków reklamowych służyć miały nowe formy reklamy (np. lokowanie produktów, reklama natywna), a przede wszystkim lepsze badanie rynku odbiorców umożliwiające precyzyjne targetowanie i dostęp do wybranych grup klientów, a tym samym większą skuteczność przekazów reklamowych. Wzrost wartości rynku reklamy zapewniać miało również dalsze wydłużanie czasu korzystania z mediów przez odbiorców, na przykład poprzez dostęp mobilny oraz multiscreening (dostęp do treści medialnych na różnych ekranach).

Paradoksalnie, wiele z tych czynników postrzegano jako zagrożenia dla rozwoju rynku reklamy. Wzrost liczby kanałów dystrybucji treści medialnych powodował fragmentację odbiorców i samego rynku mediów. Z roku na rok ubywało wysokoratingowych mediów pozwalających reklamodawcy dotrzeć do wielomilionowego audytorium. Podstawowym parametrem w rozliczeniach między firmami medialnymi a reklamodawcami były bowiem punkty GRP (Gross Rating Point). Jeden punkt GRP stanowiło jednorazowe dotarcie z przekazem reklamowym do $1 \%$ docelowej grupy klientów. Zmniejszenie audytoriów oznaczało więc zmniejszenie skuteczności reklamy. Żeby zbudować odpowiedni zasięg swoich przekazów, reklamodawcy zmuszeni byli korzystać $\mathrm{z}$ wielu mediów. Podnosiło to koszty reklamy i zwiększało tzw. clutter reklamowy. Odbiorcy, zmęczeni agresywną, często powtarzaną, a przede wszystkim niedostosowaną do ich potrzeb reklamą, starali się jej unikać. Blokowanie reklam lub korzystanie z mediów pozbawionych reklamy powodowało dalsze ograniczenia w możliwościach dotarcia $\mathrm{z}$ komunikatem reklamowym, wzrost cen reklam i spadek ich skuteczności.

Mimo to media funkcjonujące $w$ internecie oferowały coraz wyższe ratingi (zasięgi reklamy w grupach docelowych), precyzyjne targetowanie (przekazywanie komunikatów reklamowych ściśle określonym grupom odbiorców) oraz dokładne mierzenie efektów reklamy (dzięki umożliwieniu natychmiastowego zakupu reklamowanego produktu). Jak podkreślali specjaliści zajmujący się badaniami marketingowymi, w mediach tradycyjnych nie mierzyło się bowiem skuteczności reklamy (np. wzrostu sprzedaży reklamowanych produktów), tylko liczbę osób, które potencjalnie zapoznały się z komunikatem reklamowym ${ }^{3}$.

3 Por. wskaźniki, którymi posługują się agencje reklamowe. 


\section{Wydatki konsumenckie na media}

Na skutek zmniejszenia wpływów reklamowych w tradycyjnych mediach wzrosło znaczenie opłat wnoszonych za korzystanie z treści medialnych przez użytkowników. Specjalizacja mediów i lepsze dopasowanie ich oferty do oczekiwań odbiorców miały zwiększać skłonność do płacenia za media i uniezależniać je od rynku reklamy. Spersonalizowane, odpowiadające potrzebom społecznym media miały być wolne od marketyzacji i utowarowienia, służyć rozwojowi demokracji i zwiększać dobrobyt społeczny (zob. Schiller 1996, s. 35).

Według raportu „World Press Trends 2015” przychody ze sprzedaży treści czytelnikom już w 2014 roku były w światowej prasie wyższe niż przychody ze sprzedaży reklam (WAN-IFRA 2015). W Polsce ten trend widać chociażby na przykładzie Gazety Wyborczej, której przychody reklamowe od 2008 do 2018 roku spadły ponad pięciokrotnie (z prawie $500 \mathrm{mln}$ zł do nieco ponad $80 \mathrm{mln}$ zł), a przychody ze sprzedaży egzemplarzowej w tym samym czasie tylko o $40 \%$ (ze $152 \mathrm{mln}$ zł do $92 \mathrm{mln}$ zł) ${ }^{4}$.

Opłaty od widzów już od lat są głównym źródłem przychodów branży telewizyjnej. Według szacunków rynek płatnej telewizji w Polsce wart był w 2009 roku 4-5 mld zł (UOKiK 2011), a w 2013 roku nawet 7 mld zł (KRRiT 2016). Wartość polskiego rynku reklamy telewizyjnej netto wynosiła w tym czasie niespełna 4 mld zł.

Odwrócenie proporcji w finansowaniu mediów świadczy o przeobrażeniach w systemie komunikacji społecznej. Optymistyczne modele biznesowe, na przykład zasada „długiego ogona” (Anderson 2008), zakładają nawet, że w gospodarce cyfrowej, dzięki zmniejszeniu kosztów produkcji i dystrybucji, zyskowna będzie sprzedaż produktów wyłącznie użytkownikom, w tym na rynkach niszowych, chociaż nie gwarantują one wysokich wpływów reklamowych. Specyfice produktów medialnych bardziej jednak odpowiada klasyczna teoria „80/20” (tzw. zasada Pareto ${ }^{5}$ ), bo tłumaczy związek między popularnością produktu wśród odbiorców a wysokimi wpływami reklamowymi. Dlatego zarówno tradycyjni, jak i cyfrowi producenci mediów walczą o utrzymanie obu źródeł finansowania. Spadek liczby użytkowników pociąga bowiem za sobą obniżenie wpływów reklamowych; z kolei spadek przychodów reklamowych - wzrost ceny mediów dla użytkowników.

Czynniki, które wpływają na indywidualną konsumpcję mediów, można podzielić na ekonomiczne (m.in. dochody ludności, ceny, zasoby materialne ludności, podaż, system dystrybucji) i pozaekonomiczne (czynniki demograficzne, społeczne, psychologiczne i kulturowe). Popyt na media jest zjawiskiem, które dynamicznie ewoluuje i wymaga stałej redefinicji. Niemniej jednak poziom dochodów w dyspozycji gospodarstw domowych warunkuje wydatki na konsumpcję dóbr kultury, $\mathrm{w}$ tym na korzystanie z mediów.

4 Por. Agora, Sprawozdania Zarządu z działalności Grupy Agora S.A. (Agora 2008-2018).

5 Zasada sformułowana przez Josepha Jurana na podstawie badań Vilfreda Pareto na temat nierównej dystrybucji bogactwa zakłada, że duża część rezultatów jest spowodowana małą częścią przyczyn, np. $80 \%$ przychodów pochodzi ze sprzedaży $20 \%$ najbardziej popularnych produktów. 
W Polsce przeciętne wydatki gospodarstw domowych na kulturę stanowią niewielką część wszystkich wydatków. W latach 2007-2015 ich udział w łącznych wydatkach nie przekroczył 4\%, mimo że w tym okresie wydatki gospodarstw domowych ogółem systematycznie wzrastały (GUS 2016, s. 47). Udział wydatków na kulturę w łącznych wydatkach gospodarstw domowych w 2017 roku wyniósł 2,5\% (GUS 2018). Wydatki na kulturę stanowią relatywnie stały odsetek wydatków konsumenckich. Konsumenci wydają na kulturę o tyle więcej, o ile się bogacą. W społeczeństwach rozwiniętych udział wydatków na kulturę w wydatkach konsumenckich wynosi 3-5\%.

W strukturze wydatków gospodarstw domowych na kulturę corocznie największy udział mają wydatki na media. Opłaty radiowo-telewizyjne w 2017 roku stanowiły około $30 \%$ wszystkich wydatków gospodarstw domowych na kulturę w Polsce, zakup sprzętu audiowizualnego wraz z odpowiednimi akcesoriami prawie $10 \%$, a wydatki na zakup gazet i czasopism 8\% (GUS 2018).

Zgodnie z potwierdzoną licznymi badaniami hipotezą dotyczącą stałości wydatków na media, ich udział w wydatkach konsumpcyjnych ludności w dłuższych okresach pozostaje względnie stabilny, natomiast zmiana popytu na poszczególne media odbywa się poprzez relokację wydatków, a nie ich zwiększanie (McCombs 1972). I tak wzrost popularności telewizji i wideo odbył się kosztem wydatków na kino (Docherty et al. 1986), zwiększenie wydatków na media audiowizualne zmniejszyło wydatki konsumenckie na media drukowane, a wzrost wydatków na internet i inne nowe media odbija się na zakupach wszystkich mediów tradycyjnych.

Wydatki na media (zakup prasy ${ }^{6}$ oraz opłaty za telewizję ${ }^{7}$ w strukturze wydatków polskich gospodarstw domowych również mają względnie stabilny udział wynoszący około 1,7\% wydatków gospodarstw domowych na osobę (wykres 4). Zmniejszenie tego udziału w 2013 roku i kolejnych latach wynikało ze zmiany sposobu klasyfikacji wydatków (do działu „Łączność” przesunięto opłaty za usługi internetowe oraz abonament za telewizję płacony w pakiecie telekomunikacyjnym), a nie ze zmniejszenia wydatków na media elektroniczne (GUS 2014). Tym niemniej struktura wydatków na media uległa zasadniczej zmianie. Sukcesywnie malały nominalne wydatki na zakup gazet i czasopism oraz ich udział w wydatkach gospodarstw domowych, a wzrastały wydatki na media cyfrowe i elektroniczne.

6 Składa się na niego zakup gazet i czasopism oraz opłaty za prenumeratę, w tym internetową (por. GUS 2013).

7 Opłaty za telewizję to abonament radiowo-telewizyjny, abonament za telewizję kablową, cyfrową, opłaty za telewizję na żądanie. Od 2013 roku nie zalicza się do nich opłat za dostęp do programu telewizyjnego w ramach pakietu telekomunikacyjnego (ujętych w dziale „Łączność”) (por. GUS 2013). 
Wykres 4. Udział w wydatkach na media (w \%) w miesięcznych wydatkach gospodarstw domowych na osobę w latach 2008-2017

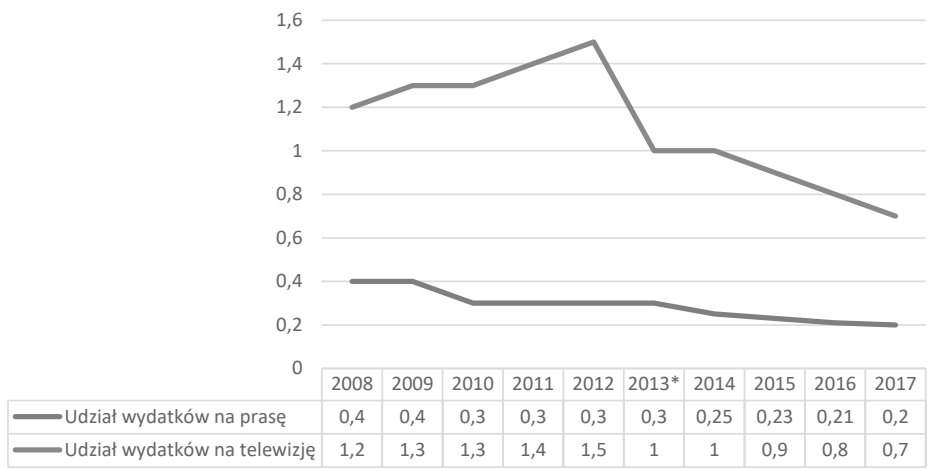

*Zmiana sposobu klasyfikacji wydatków na telewizję

Źródło: Wyliczenia własne na podstawie danych GUS. GUS (2011) i kolejnych.

Udział wydatków na zakup prasy w budżetach gospodarstw domowych zmniejszał się od lat 90. XX wieku ${ }^{8}$, ale szczególnie silne spadki zaznaczyły się w XXI wieku. Miesięczne wydatki na zakup prasy (około 2,4 zł na osobę) oznaczają, że statystyczne czteroosobowe gospodarstwo domowe kupuje zaledwie jeden tytuł tygodniowo (najpewniej z programem telewizyjnym).

W przypadku opłat radiowo-telewizyjnych wydatki gospodarstw domowych rosły systematycznie do 2012 roku, głównie za sprawą zwiększonych opłat za telewizję kablową i cyfrową. Spadek tych wydatków od 2013 roku można tłumaczyć, poza zmianą sposobu klasyfikacji wydatków, spadkiem cen abonamentów oraz rezygnacją z płatnej telewizji kablowo-satelitarnej na rzecz bezpłatnej cyfrowej telewizji naziemnej oraz treści audiowizualnych dostępnych w internecie.

Wzrost konsumpcji treści medialnych $w$ internecie nie znajduje odzwierciedlenia w statystyce publicznej. Wprawdzie może o niej świadczyć rosnący odsetek gospodarstw domowych $\mathrm{z}$ dostępem do internetu, $\mathrm{w}$ tym szerokopasmowego, ale liczba użytkowników internetu9 niewiele mówi nam o liczbie osób korzystających $\mathrm{z}$ mediów online. Jeszcze mniej wiadomo o wydatkach konsumentów na treści medialne $\mathrm{w}$ internecie.

Konwergencja mediów sprawia, że duża część pieniędzy konsumentów trafia do przedsiębiorców telekomunikacyjnych oferujących pakiet telefonii, internetu (głównie mobilnego) i płatnej telewizji. $\mathrm{Z}$ danych polskiego regulatora rynku elektronicznego wynika, że w 2017 roku z usług wiązanych (pakietów) korzystało

8 W 1993 roku wynosił ponad 0,63\% wydatków ogółem i 19\% wydatków na kulturę (por. GUS 1994).

9 Jak wynika z ostatniego raportu firmy doradczej Deloitte, z internetu aktywnie korzysta w Polsce blisko $26 \mathrm{mln}$ osób. Blisko $90 \%$ łączy się z siecią za pomocą urządzeń mobilnych. Wiąże się to z jednej strony z tym, że dysponujemy coraz większą liczbą smartfonów (jest ich w Polsce o wiele więcej niż mieszkańców), a ceny internetu mobilnego maleją i są jednymi $\mathrm{z}$ najniższych w Europie. 
10,15 mln osób. Przychody branży telekomunikacyjnej w Polsce wyniosły w 2017 roku 39,5 mld zł (UKE 2018). Nie wiadomo jednak, jak duża część tej kwoty była opłatą za dostęp do treści medialnych.

Polscy internauci, kupując dostęp do internetu, rzadko skłonni byli płacić za konkretne treści medialne. Modele subskrypcyjne (stała opłata za dostęp do treści) ustępowały popularnością modelom reklamowym (dostęp do treści w zamian za obejrzenie reklamy). Duży był też margines nieautoryzowanego dostępu do treści medialnych. Na przykład skalę piractwa treści wideo w internecie szacowano w Polsce w 2013 roku na 7-10 mln osób, a wartość utraconego wskutek piractwa PKB na poziomie 500-700 mln złotych (PwC 2014). Badania z 2016 roku wskazywały, że liczba osób korzystających z nielegalnych treści wideo przekraczała $8 \mathrm{mln}$, a straty tym wywołane wyniosły około 1,7 mld złotych (Deloitte 2017).

\section{Zmiana kosztów produkcji i dystrybucji mediów}

Społeczne przyzwolenie na nieautoryzowane korzystanie z treści medialnych wynikało z przekonania, że technologia cyfrowa zmniejszyła znacznie koszty produkcji, a przede wszystkim reprodukcji i dystrybucji informacji. W ich tworzenie i upowszechnianie, oprócz firm medialnych, zaangażowały się jednostki i społeczności. Internet stał się commons - przestrzenią wspólną, która pozwalała na swobodną komunikację i wymianę informacji.

Współdzielenie zasobów dość szybko jednak zaczęło być kontrolowane przez pośredników i uległo komercjalizacji. Jak ujął to Sławomir Czetwertyński:

[...] odpowiednie wykorzystanie korzyści płynących z niskich kosztów reprodukcji produktów wirtualnych, przy jednoczesnej minimalizacji zaangażowania rzeczywistych czynników produkcji, jest źródłem sukcesów wielu przedsiębiorstw. Strategie tych przedsiębiorstw opierają się głównie na pośrednictwie, a nie faktycznym wytwarzaniu produktów wirtualnych. Spółka Apple Inc. za pośrednictwem sklepu internetowego iTunes Store sprzedaje utwory muzyczne, których de facto nie produkuje. Koszty wytworzenia ponoszą wytwórnie lub sami artyści, jednocześnie ponosząc ryzyko opłacalności zaangażowania rzadkich zasobów (Czetwertyński 2015, s. 205).

Na podobnej zasadzie działały agregatory treści prasowych oraz serwisy gromadzące biblioteki treści audio-wideo i sprzedające dostęp do nich (np. Spotify czy Netflix). Pozarynkowa wymiana dóbr i usług znajdujących się w posiadaniu użytkowników została zastąpiona sprzedażą dostępu do zasobów będących własnością firm.

Szczególnie duże zyski zaczęły osiągać firmy, które wykorzystując darmową pracę wykonywaną przez użytkowników mediów społecznościowych (tworzenie lub udostępnianie treści medialnych, ich archiwizowanie, porządkowanie, tłumaczenie, komentowanie, propagowanie itp.), sprywatyzowały wartości przez nich współtworzone (Terranova 2010). 


\section{Podsumowanie}

Zmiany struktury kosztów produkcji medialnej i ich wpływ na przekształcenia struktury zatrudnienia i udziału płac w gospodarce jako całości nie podlegają badaniu. Wpływają na to między innymi praktyki transferowania przychodów za granicę przez nowomedialnych gigantów typu Google, Apple oraz nieujawnianie przychodów reklamowych przez największe firmy internetowe.

Wydatki na reklamę cyfrową w Polsce w 2018 roku wynosiły, według szacunków, około 4,5 mld zł (IAB/PwC 2018). Na reklamę display, w której duży udział mają wydawcy prasy, przeznaczono prawie połowę tej kwoty. Jednocześnie około $30 \%$ budżetów reklamowych, czyli 1,35 mld zł, pochłonęła reklama w wyszukiwarkach, a około 18\%, czyli $800 \mathrm{mln}$ zł, przeznaczono na reklamę w mediach społecznościowych. Uznaje się, że pieniądze te trafiły do Google i Facebooka, czyli podmiotów, które tylko agregują linki do treści wytworzonej przez wydawców albo są platformami je pokazującymi (wyszukiwarki internetowe, serwisy social media).

Specjaliści podkreślają, że udział w reklamie cyfrowej zapewnia już nie tylko zasięg witryny i statystyki oglądalności, ale umiejętność zbierania i wykorzystania danych związanych z tożsamością internautów, ich upodobaniami, statusem społecznym.

Mnogość platform dystrybucji treści medialnych, nowe praktyki konsumpcji mediów i nowe formy reklamy utrudniają ocenę wpływu mediów na gospodarkę i ich znaczenie ekonomiczne. Dotychczasowe standardy pomiaru użytkowników mediów na wszystkich platformach wzbudzają liczne kontrowersje, zwłaszcza że poza monitoringiem znajduje się wiele znaczących podmiotów medialnych.

Internet, zmieniając koszty produkcji dóbr cyfrowych (zwłaszcza obniżając koszty krańcowe, koszt dystrybucji oraz koszty transakcyjne), sprawił, że stały się one w dużej mierze przedmiotem nieformalnej, pozarynkowej wymiany. Nie stworzono do tej pory metod badania udziału użytkowników mediów w rynku medialnym oraz ich wpływu na strukturę i wartość tego rynku.

\section{Bibliografia}

Agora (2008-2018). Sprawozdania Zarządu z działalności Grupy Agora S.A. za lata 2008-2018 [https://www.agora.pl/dla-inwestorow; 27.03.2019].

Anderson C. (2008). Długi ogon. Ekonomia przyszłości - każdy konsument ma głos. Poznań.

Andras T.L., Srinivasan S. (2003). Advertising Intensity and R\&D Intensity. Differences across Industries and Their Impact on Firm's Performance. International Journal of Business and Economics, no. 2, p. 167-176.

Czetwertyński S. (2015). Problem rzadkości w Internecie. Studia Ekonomiczne, nr 139, s. 198-206.

Deloitte (2017). Piractwo w Internecie - straty dla kultury i gospodarki. Analiza wpływu zjawiska piractwa internetowego na gospodarkę Polski na wybranych rynkach kultury. Warszawa. Demers D.P. (1994). Relative Constancy Hypothesis, Structural Pluralism, and National Advertising Expenditures. Journal of Media Economics, no. 4, p. 31-48. 
Dimmick J. (1997). The Theory of the Niche and Spending on Mass Media. The Case of Video Revolution. The Journal of Media Economics, no. 3, p. 33-43.

Docherty D. et al. (1986). The British Film Industry and the Declining Audience: Demythologizing the Technological Threat, Journal of Communication, no. 36, p. 27-39.

Ecorys (2006). Analiza potrzeb i rozwoju przemysłów kreatywnych. Warszawa.

Ernst \& Young (2014). Kultura jako źródło wzrostu gospodarczego w Unii Europejskiej. Analiza rynków kreatywnych [http://www.zaiks.org.pl/view/296/ey_analiza_rynkow_kreatywnych. pdf; 3.04.2017].

European Competitiveness Report (2010). Working Staff Document, Bruksela 28.10.2010, SEC 1276. GUS (1994). Kultura w 1993 r. Warszawa.

GUS (2008-2018). Informacja w sprawie skorygowanego szacunku PKB za poszczególne lata [https://stat.gov.pl/obszary-tematyczne/rachunki-narodowe/; 27.03.2019].

GUS (2011). Kultura w 2010 r. Warszawa.

GUS (2013). Kultura w 2012. Warszawa.

GUS (2014). Budżety gospodarstw domowych w 2013 r. Warszawa.

GUS (2016). Finanse kultury w latach 2007-2015. Kraków.

GUS (2018). Kultura w 2017. Warszawa.

IAB/PwC (2018). AdEx.

IBS (2010). Znaczenie gospodarcze sektora kultury. Wstęp do analizy problemu. Warszawa

IBS (2017). Znaczenie gospodarcze sektora kultury w Polsce w latach 2008-2015. Warszawa.

Jakubowicz K., Jung B., Kowalski T. (2004). Polityka państwa polskiego w dziedzinie mediów elektronicznych oraz nowelizacji innych ustaw (tzw. Biała księga). Warszawa.

KE (2010a). Zielona Księga w sprawie uwalniania potencjału przedsiębiorstw z branży kultury i branży twórczej [http://ec.europa.eu/culture/documents/greenpaper_creative_industries_ pl.pdf; 27.01.2019].

KE (2010b). Europa 2020. Strategia na rzecz inteligentnego i zrównoważonego rozwoju sprzyjającego włączeniu społecznemu [https://ec.europa.eu/eu2020/pdf/1_PL_ACT_part1_v1.pdf; 22.11.2017].

KEA (2006). European Affairs, The Economy of Culture in Europe [http://www.keanet.eu/ecoculture/studynew.pdf; 27.01.2019].

Kowalski T., Jung B. (2006). Media na rynku. Wprowadzenie do ekonomiki mediów. Warszawa. KRRiT (2016). Informacja o podstawowych problemach radiofonii i telewizji w 2015 roku. Warszawa. McCombs M.E. (1972). Mass Media in the Marketplace. Journalism Monographs, no. 24, p. 21-32. PE (2013). Rozporządzenie Parlamentu Europejskiego i Rady (UE) nr 1295/2013 z dnia 11 grudnia 2013 r. ustanawiające program „Kreatywna Europa” (2014-2020) [https://eur-lex.europa.eu/ legal-content/PL/TXT/?uri=CELEX:32013R1295; 22.11.2018].

PE (2016). Projekt rezolucji parlamentu europejskiego w sprawie spójnej polityki UE dla sektora kultury i sektora kreatywnego (2016/2072(INI)) [http://www.europarl.europa.eu/sides/ getDoc.do?pubRef=-//EP//TEXT+REPORT+A8-2016-0357+0+DOC+XML+V0//PL\&language $=$ pl; 27.01.2017].

Picard R.G. (2001). Effects of Recessions on Advertising Expenditures: An Exploratory Study of Economic Downturns in Nine Developed Nations. Journal of Media Economics, no. 1, p. 1-14. PwC (2014). Analiza wpływu zjawiska piractwa treści wideo na gospodarkę w Polsce. Warszawa. Schiller H.I. (1996). Information Inequality. The Deepening Social Crisis in America. London. 
Starlink/Starcom (2008-2018). Raporty o rynku reklamowym w poszczególnych latach [w posiadaniu autorki i publikowane m.in. przez wirtualnemedia.pl].

Strategia rozwoju rynku medialnego w Polsce 2015-2020 (2015). W. Dziomdziora (red.). Warszawa. TERA Consultants (2010). Building a Digital Economy. The importance of saving jobs in the UE's creative industries. Paris [http://www.teraconsultants.fr/assets/publications/PDF/2010-Mars-Etude_Piratage_TERA_full_report-En.pdf.; 24.06.2017].

Terranova T. (2010). New Economy, Financialization and Social Production in the Web 2.0. W: A. Fumagalli, S. Mezzadra (eds.). Crisis in the Globar Economy. Financial Markets, Social Struggles, and New Political Scenarios. Los Angeles.

UKE (2018). Raport o stanie rynku telekomunikacyjnego w Polsce w 2017 r. Warszawa.

UOKiK (2011). Raport z badania rynku usług dostępu do płatnej telewizji [http://www.press. pl/attachments/www-data/Raport-UOKiK-z-badania-rynku-dostepu-platnej-telewizji_171. pdf; 27.06.2017].

van der Wurff R. et al. (2008). Economic Growth and Advertising Expenditures in Different Media in Different Countries. Journal of Media Economics, no. 1, p. 28-52.

WAN-IFRA (2015). World Press Trends 2015 [http://www.wan-ifra.org/microsites/world-press-trends; 22.11.2015].

Woźniczka J. (2014). Czynniki warunkujące związek między gospodarką a reklamą. Konsumpcja i Rozwój, nr 3(8), s. 3-15.

\section{STRESZCZENIE}

Ekonomiczne analizy udziału mediów w gospodarce opierają się na pomiarach wydatków reklamowych i konsumenckich na media. Nie uwzględniają one zmiany kosztów produkcji i dystrybucji mediów z powodu ich cyfryzacji. Nowe technologie doprowadziły do pozainstytucjonalnej produkcji i dystrybucji mediów, sprywatyzowania zysków i uspołeczniania kosztów produkcji mediów. Wymaga to opracowania nowych wskaźników pomiaru oddziaływania przemysłu medialnego na gospodarkę.

Autorka, opierając się na ogólnodostępnych danych, prezentuje różne metody badania wartości ekonomicznej mediów tradycyjnych. Zwraca jednocześnie uwagę, że ich malejący udział w gospodarce spowodowany jest nieuwzględnianiem w statystyce publicznej wydatków konsumentów na treści medialne w internecie oraz przychodów firm medialnych $\mathrm{z}$ reklamy online. Sygnalizuje też, że cyfryzacja mediów (w tym wirtualizacja produkcji i konsumpcji treści medialnych) zmieniła definicję przemysłu medialnego i granice tzw. branży medialnej.

Słowa kluczowe: ekonomika mediów, udział mediów w gospodarce, wydatki konsumentów, przychody reklamowe, metody badań 